\title{
NOTES ON THE DISTRIBUTIONS AND TAXONOMY OF TWO SPECIES OF FRESHWATER CRABS OF THE GENUS ISOLAPOTAMON BOTT, 1968 (DECAPODA, BRACHYURA, POTAMIDAE) FROM SARAWAK, MALAYSIA
}

\author{
BY \\ J. GRINANG ${ }^{1,3}$ ), P. K. L. NG ${ }^{2}$ ) and I. DAS ${ }^{1}$ ) \\ 1) Institute of Biodiversity and Environmental Conservation, Universiti Malaysia Sarawak, \\ 94300 Kota Samarahan, Sarawak, Malaysia \\ 2 ) Lee Kong Chian Natural History Museum, Faculty of Science, National University of Singapore, \\ 6 Science Drive 2, 117543 Singapore
}

\begin{abstract}
Of the seven species of potamid freshwater crabs of the genus Isolapotamon Bott, 1968, known from Sarawak, the type localities of two species, I. borneense $\mathrm{Ng} \& \mathrm{Tan}, 1998$, and I. grusophallus Ng \& Yang, 1986, are not known with accuracy. Through extensive collections in Sarawak, the provenances of these localities are now determined. Isolapotamon borneense is found in the upper parts of the Baram River in northern Sarawak; while I. grusophallus occurs in Gunung Penrissen and adjacent areas in central Sarawak. The taxonomy of these two species is also discussed.
\end{abstract}

\section{RÉSUMÉ}

Parmi les sept espèces de crabes d'eau douce Potamidae du genre Isolapotamon Bott, 1968, connus de Sarawak, les localités-types de deux espèces, I. borneense $\mathrm{Ng} \& \mathrm{Tan}, 1998$, et I. grusophallus Ng \& Yang, 1986, n'étaient pas connues avec précision. Grâce aux importantes collections réalisées au Sarawak, la situation des ces localités est maintenant déterminée. Isolapotamon borneense se trouve dans les parties supérieures du fleuve Baram dans la région nord du Sarawak ; tandis que I. grusophallus se rencontre dans le Gunung Penrissen et les régions adjacentes dans le Sarawak central. La taxonomie de ces deux espèces est également discutée.

\section{INTRODUCTION}

The potamid crab genus Isolapotamon Bott, 1968 (type species Potamon anomalus Chace, 1938) is currently represented by 19 species from Borneo and

3) Corresponding author; e-mail: gjongkar@ibec.unimas.my

(C) Koninklijke Brill NV, Leiden, 2014 